\title{
Enhancement of Seedling Vigour through Bio-priming for Barnyard Millet Var. MDU 1
}

\author{
S. Iswariya ${ }^{1}$, K. Sujatha ${ }^{2} *$ and R. Subhashini ${ }^{3}$ \\ Department of Seed Science and Technology, Agricultural College and Research Institute, \\ Madurai -625 104, Tamil Nadu, India \\ *Corresponding author
}

\begin{tabular}{|c|c|}
\hline & \\
\hline & \multirow{3}{*}{$\begin{array}{l}\text { The experiment was conducted to determine the enhancement of seedling vigour } \\
\text { through bio priming for barnyard millet. Seeds of barnyard millet var. MDU } 1 \\
\text { were bioprimed with water, Azophos, Pseudomonas fluroscens, PPFM and the } \\
\text { combinations of Azophos+ Pseudomonas fluroscens at } 20 \% \text { concentration for } 8 \mathrm{~h} \text {. } \\
\text { Bio- primed seeds were evaluated for its germination, seedling length, vigour } \\
\text { index, dehydrogenase, } \alpha \text {-amylase and microbial count. Results revealed that seeds } \\
\text { bioprimed with Azophos+ Pseudomonas fluroscens @ } 20 \% \text { for } 8 \mathrm{~h} \text { performed } \\
\text { positive influence on physiological quality and biochemical parameters. In } \\
\text { addition microbial population of } 107 \times 10^{4} \text { CFU g }{ }^{-1} \text { of seed was observed in } \\
\text { Azophos+ Pseudomonas fluroscens primed seeds compared to other priming } \\
\text { treatments. These treatments can be utilized for enhancing seedling vigour in } \\
\text { barnyard millet. }\end{array}$} \\
\hline & \\
\hline & \\
\hline
\end{tabular}

\section{Introduction}

Small millets are nothing but group of small millet grasses. The group comprising of finger millet, kodo millet, little millet, foxtail millet, barnyard millet and proso millet are considered as "Nutricereals" and are a source of food, feed and fodder. They are known for resilience and drought enduring capacity and are well suited for contingency crop planning, addressing the issues of climate change. Millets in general provide many essential vitamins and micronutrients that can bolster nutrition for those living in dryland areas. They are especially rich in iron, calcium and zinc, and have other dietary qualities that can help stave off anemia, celiac disease, and diabetes.

Now-a-days unpredictable and inconsistent rainfall, poor quality seeds and changing environment conditions affect the crop establishment and leading to crop failure. Among the different means of solutions, seed priming is one of the simple and low cost technology especially for dry land farmers. Seed priming is a controlled hydration process that involves exposing seeds to low water potential that restrict germination, but permits pre-germinative physiological and 
biochemical changes to occur (Rink et al., 2017). Different priming methods are followed by researchers. One of the best and ecofriendly priming method is biopriming. The seed biopiming is an effective seed treatment to increase the rate, uniformity of emergence and crop establishment in most of the crops especially in advanced countries it integrates the biological and physiological aspects of enhancing growth, disease control and increase in yield. Excessive and continuous use of chemical fertilizers coupled with pesticides and fungicides have damaged the soil fertility which causes deleterious effects on crop cultivation and productivity. Now-a-days, chemical fertilizers are replaced by environment friendly biofertilizers. Biofertilizers improve the root development, vegetative growth and nitrogen fixation. They liberate growth promoting substances and vitamins and help to maintain soil fertility, improve physical properties of soil, soil health in general and help in the bio-control of disease. The reports on positive and significant response of biopriming alone or combinations on physiological quality in barnyard millet is very meager therefore the present study was carried out to identify the effect of bio priming in barnyard millet.

\section{Materials and Methods}

Genetically pure and fresh barnyard millet var MDU 1 seeds were collected from Department of Seed Science and Technology, Agricultural College and Research Institute, Madurai. Bioinoculants viz., Azospirillum (SP 7), Phosphate Solubilizing bacteria ( $\mathrm{Pb}-1)$, Potash release bacteria (KRB 7), Pinkpigmented facultative methylotrophic bacteria (PPFMs) and Pseudomonas fluroscens, Silicate Solubilizing bacteria (SSB-7) were obtained from Department of Agricultural Microbiology, Agricultural College and Research Institute, Madurai, Tamil Nadu.
The strains were cultured in specific culture media for each. Liquid based bio-inoculant formulations were prepared for priming the seeds. Broth at different concentrations viz., 5, $10,20 \%$ was prepared. The seeds were soaked in respective solution with duration of 6,8 and 12 hours with 1:1 ratio (v/w). After the priming treatments the seeds were shade dried to original moisture content of $12 \%$ and germination test was conducted (ISTA, 1999) with four replicates of 100 seeds in paper towels. The test conditions were $25 \pm 2^{\circ} \mathrm{C}$ temperature, $95 \pm 5 \%$ Relative Humidity and illumination with fluorescent light (750-1250 lux). Final count of normal seedling was recorded on $7^{\text {th }}$ day.

Observations on germination, seedling length and vigour index were recorded. Biochemical parameters viz.,dehydrogenase activity (Kittock and Law 1968) were expressed as OD value @ $480 \mathrm{~nm}$ and $\alpha$-amylase activity expressed as mg maltose $\min ^{-1}$ (Paul et al., 1970) respectively. Microbial population in the bioprimed seeds was assessed. All analyses were made in duplicate. The data were statistically analysed using AGRES software. Percentage data were transformed to arcsine values wherever necessary.

\section{Results and Discussion}

Based the pilot studies the best treatments were selected and taken for research. Significant differences were observed among the treatments in which the seeds bio primed with 20\% Azophos + Pseudomonas fluroscens for $8 \mathrm{~h}$ have recorded $100 \%$ germination, root length $(15.2 \mathrm{~cm})$, shoot length $(8.8 \mathrm{~cm})$ and vigour index (2400).

The hydroprimed seeds recorded 88\%, 11.8 $\mathrm{cm}, 8.1 \mathrm{~cm}$ and 1751 for germination, root length, shoot length and vigour index respectively (Fig. 1-6). 
Fig.1 Effect of biopriming on germination percentage and vigour index in barnyard millet

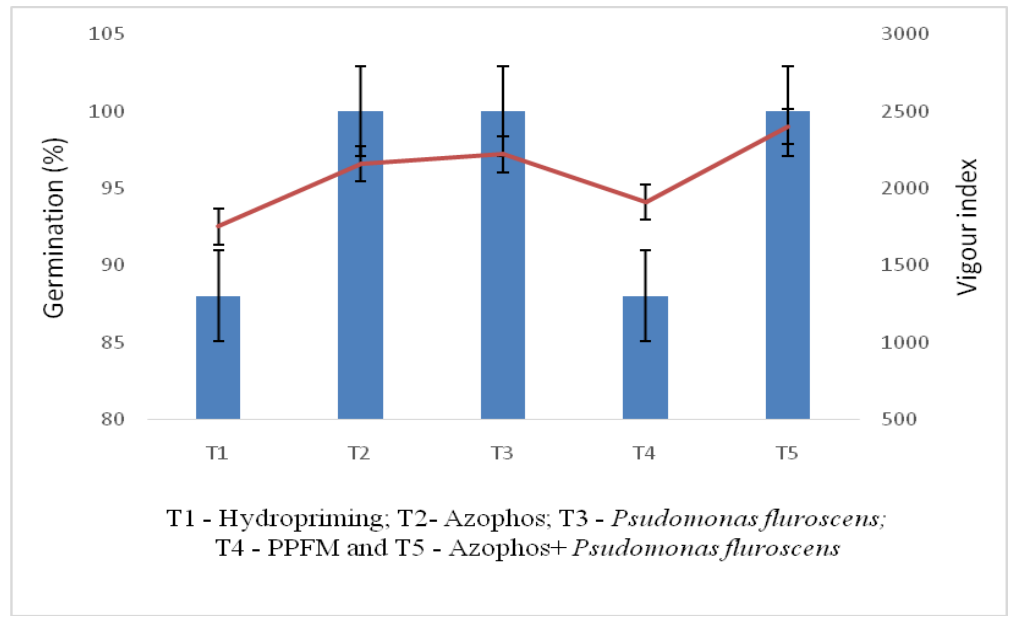

Fig.2 Effect of biopriming on root length and shoot length in barnyard millet

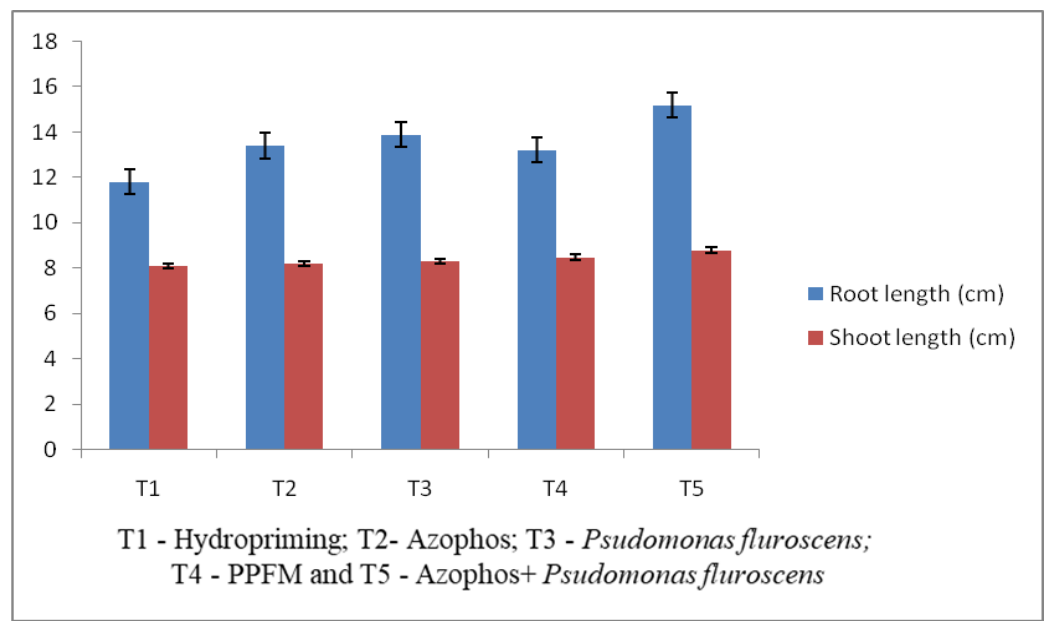

Fig.3 Effect of biopriming on microbial population in barnyard millet

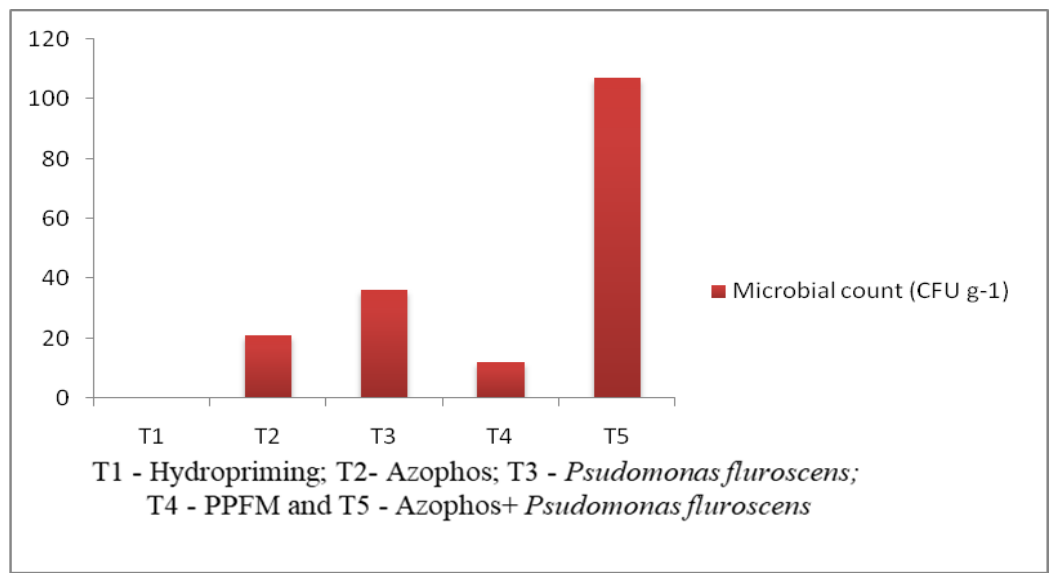


Fig.4 Effect of biopriming on dehydrogenase and $\alpha$-amylase activity in barnyard millet

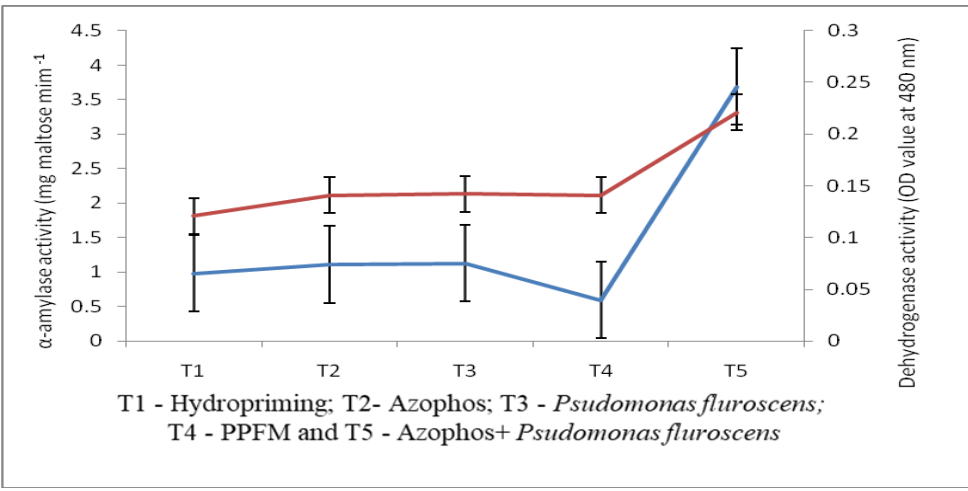

Fig.5 Seedling growth of barnyard millet $-20 \%$ at $8 \mathrm{~h}$

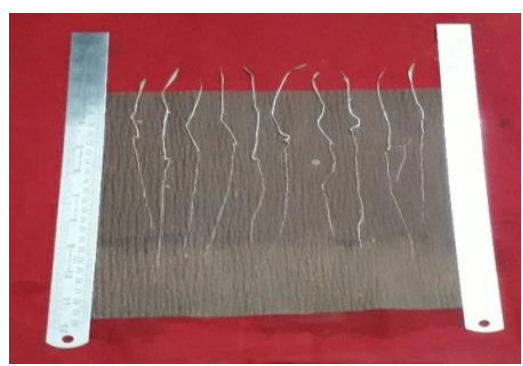

Hydroprimed

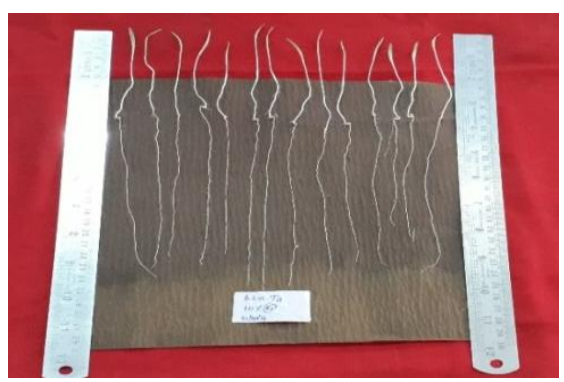

Azophos+Psudomonas fluroscens

Fig.6 Microbial population of Azophos+Pseudomonas fluroscens

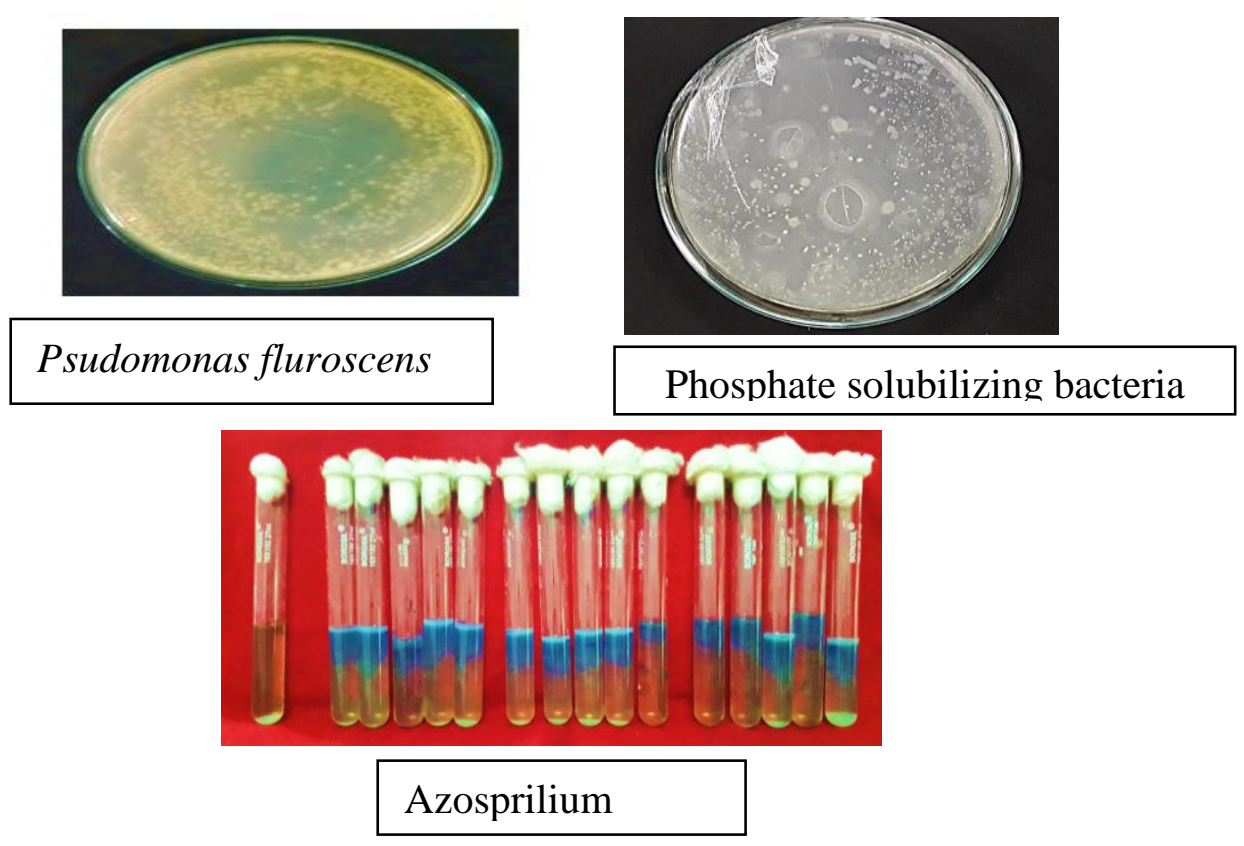


Bio priming using biological agents has PGPR activity that increase germination and improve seedling establishment and proliferation of PGPR on the spermosphere (Taylar and Harman, 1990).

Seed biopriming with Azophos + Pseudomonas fluroscens might have stimulated the hypocotyl and epicotyl growth and cell elongation by inducing secretion of $\mathrm{GA}_{3}$ resulting in increased root length and shoot length. Similar findings reported by Sakthivel et al., 2009 in tomato; Sivasankaridevi et al., 2013 in cucumber; Sivakalai and Krishnaveni, 2017 in pumpkin; Sridevi and Manonmani, 2016 in kodo millet and barnyard millet and Madhukeshwara et al., 2017 in maize.

Among the bioinoculants Azophos + Pseudomonas fluroscens showed higher microbial population compared to other biopriming agent $\left(107 \times 10^{4} \mathrm{CFU}\right)$. Hydroprimed seeds recorded nil microbial population. Percentage increase over control (hydropriming) was by 12, 22.36, 7.95, 27.04, $45.24,83.52$ and 100 for germination, root length, shoot length, vigour index, dehydrogenase activity, $\alpha$-amylase activity and microbial count respectively. The seed moisture availability might have maintained the viability of microorganisms in the seed. Similar findings were reported by (Anitha, 2010, Meena et al., 2012, Raja et al., 2017, Subhaswaraj et al., 2017, Nithya et al., 2017 and sivakalai and krishnaveni, 2017.

The enzyme activities of dehydrogenase and $\alpha$-amylase were recorded higher in Azophos + Pseudomonas fluroscens primed seeds. The enhancement in the seedling growth enzyme activity and microbial count noticed in this study can be attributed to suppression of deleterious microorganisms, pathogens, production of plant growth regulators such as Gibberellic acid (GA), Cytokinin, Indole acetic acid(IAA) increased availability of minerals and other ions and also more water uptake (Ramamoorthy et al., 2000). The positive effect of Azophos + Pseudomonas fluroscens bio primed seeds might be due to plant growth promoting substances or phyto hormones and also enhancing the nutrient mobilization from the seed.

It could be concluded that barnyard millet seeds soaked in equal volume of liquid microbial culture Azophos + Pseudomonas fluroscens@ $@ 20 \%$ for 8h registered higher seedling vigour.

\section{References}

Anitha, K. G. 2010. Enhancing seded germination of mono and dicotyledons through IAA production of PPFM. Trends Soils Sci. Plant Nutr. J., 1: 1418.

ISTA, (1999). International Rules for Seed Testing. Seed Sci. \& Technol., Supplement Rules, 13, 209-355.

Kittock, D., and A. Law, (1968). Relationship of Seedling Vigor to Respiration and Tetrazolium Chloride Reduction by Germinating Wheat Seeds 1. Agronomy Journal, 60(3), 286-288.

Madhukeshwara BP and Ashok S Sajjan. 2017. Influence of bio-priming on field performance and yield in maize hybrid. ACTA scientific agriculture 1(1): 16-19.

Meena, K.K., M. Kumar, M.G. Kalyuzhnaya, M.S Yandigeri, D.P. Singh, A.K. Saxena and D.K. Arora. 2012. Epiphytic pink-pigmented methylotrophic bacteria enhance germination and seedling growth of wheat (Triticum aestivum) by producing phytohormone. Antonie Van Leeuwenhoek, 101: 777-786.

Nithya N., R. Geetha, K. Sivasubramaniam, N.O. Gopal, C. Vanniarajan. 2017. Effect of biopriming on germination 
characterristics of PMK (R) 4 under salinity conditions. Int. J. Curr. Microbiol. App. Sci. 6(12): 895-904.

Paul, A.K., S. Mukh and S.M. Sircar. 1970. Metabolic changes in rice seeds during storage. Ind. J. Agric. Sci., 40(12): 1031-1036.

Raja K., K. Sivasubramaniam and R.Anandham. 2017. Manipulation of seed germination and vigour by bio priming with liquid microbial cultures in paddy (Oryza sativa L.). International journal current microbiology and applied science. 6(10): 1612-1618.

Ramamoorthy K., N. Natarajan, A. Lakshmanan. 2000. Seed biofortification with Azospirillum spp. For improvement of seedling vigour and productivity in rice (Oryza sativa L.).Seed sci. \& technol., 28:809-815.

Rinku V Patel, Krishna Y Pandya, R. T. Jasrai and Nayana Brahmbhatt. 2017. Effect of hydropriming and biopriming on seed germination of brinjal and tomato seed. Research journal of agriculture and forestry sciences 5(6):1-14.

Sakthivel U., S. Mahalakshmi, B. Karthikeyan. 2009. Studies on isolation and characterisation and its effect of seed inoculation of PGPR (Pseudomonas fluroscence) on yield of tomato. Journal of phytology 1(1): 3339.

Sivakalai R., K. Krishnaveni. 2017. Effect of bio-priming on seed yield and quality in pumpkin $\mathrm{cv} \mathrm{CO} 2$. International journal of current microbiology and applied science 6(12):85-90.

Sivasankaridevi T., M.K. Shivaprakash and C.C. Maina. 2013. Efficacy of seed biopriming enhancing vigour of cucumber (Cucumissativus L.) under biotic stress conditions. Mysore journal of agricultural science 47(1): 107-111.

Sridevi R., V. Manonmani. 2016. Seed priming effect on physiological traits of kodo millet and barnyard millet. International journal of agricultural science and research 6(4): 187-194.

Subhaswaraj, P., R. Jobina, P. Parasuraman and B. Siddhardha. 2017. Plant growth promoting activity of Pink Pigmented Facultative MethylotrophMethylobacterium extorquens MM2 on Lycopersicon esculentum L. J. App. Biol. Biotech., 5(1):42-46.

Taylor, A. G., and Harman, G. E., 1990, Concept and technologies of selected seed treatments. Апnи. Rev. Phytopathol. 28: 321-339.

\section{How to cite this article:}

Iswariya, S., K. Sujatha and Subhashini, R. 2019. Enhancement of Seedling Vigour through Bio-priming for Barnyard Millet Var. MDU 1. Int.J.Curr.Microbiol.App.Sci. 8(04): 2254-2259. doi: https://doi.org/10.20546/ijcmas.2019.804.263 